\title{
Kiedy zniesienie habilitacji będzie stymulować jakość uprawianej nauki w Polsce?
}

\author{
Maciej Żylicz
}

When dropping habilitation would aid progress in Poland?

Od wielu lat trwa w Polsce dyskusja nad zniesieniem lub utrzymaniem stopnia doktora habilitowanego. W ostatnim okresie stała się nawet bardziej intensywna w związku z krytyką nowego trybu przeprowadzania habilitacji wprowadzonego w 2010 r. w pakiecie ustaw reformujących naukę. Celem ustawowych regulacji z 2010 r. było nie tylko przyspieszenie i proceduralne ułatwienie możliwości otrzymania tego stopnia, ale przede wszystkim poprawienie poziomu prac habilitacyjnych, których wartość — w opinii różnych gremiów - systematycznie się obniżała. Niestety, także wprowadzenie nowej procedury nie zahamowało spadku jakości kandydatów do otrzymania habilitacji.

Będąc społecznym doradcą Prezydenta RP Bronisława Komorowskiego, opiniuję wnioski profesorskie przesłane przez Centralną Komisję do Kancelarii Prezydenta. W wielu przypadkach dorobek naukowy kandydatów do tytułu profesora, którzy posiadają już stopień doktora habilitowanego, jest mniejszy lub równoważny z dorobkiem naukowym osób ubiegających się o stopień doktora. A około 10-15\% tych wniosków, pozytywnie już opiniowanych przez CK, jest na wyjątkowo niskim poziomie. To znaczy, że procedura uzyskiwania stopnia doktora habilitowanego jest wadliwa i nie gwarantuje spełnienia celu ustawowego, czyli że tylko bardzo dobrzy kandydaci mogą uzyskać habilitację.

Nadal habilitacji nie „robi" się przy okazji prowadzenia intensywnych badań naukowych. Jeden z laureatów konkursów FNP napisał: "musiałem na pół roku przestać pracować naukowo, bo musiałem zrobić habilitację”. „Robienie” habilitacji to proces wymagający strategicznego myślenia w perspektywie wielu lat, a także opracowania taktyki postępowania. Nawet świetny dorobek naukowy nie gwarantuje sukcesu w tej procedurze. W tej strategii, która nie ma nic wspólnego z jakością badań naukowych, trzeba podejmować decyzje, gdzie i w jakiej liczbie opublikować pracę, czy mają to być monografie czy artykuły, trzeba też przewidzieć, kto może być recenzentem habilitacji i dostosować się do preferencji recenzentów, czasami wbrew dobrym praktykom uznanym w danej dziedzinie/dyscyplinie naukowej.

Wiele Rad Wydziałów i Rad Naukowych Instytutów wyznacza tak zwane liczbowe minima, które należy spełnić, aby rozpocząć procedurę habilitacyjną. Zazwyczaj minima te są oparte na liczbie publikacji oraz tak zwanym „impact factorze" czasopisma, w którym prace zostały opublikowane. Takie podejście promuje liczbę, a nie jakość prowadzonych badań naukowych. Promuje bylejakość! Sytuacja jest alarmująca, gdy młodzi naukowcy, zapytani o swoje najważniejsze osiągnięcie naukowe, odpowiadają, że opublikowali pracę w "wysoko punktowanym” czasopiśmie, ale nie są w stanie wyjaśnić, na czym to osiągnięcie polega. Ci młodzi naukowcy stali się już kolekcjonerami punktów, zapominając o merytorycznym znaczeniu swojej pracy naukowej.

Doszło do sytuacji, że aby spełnić minima liczbowe narzucone przez Rady Wydziału habilitantom, opłaca się nawet dzielić prace i publikować wiele cząstkowych artykułów w słabych czasopismach, mimo iż z góry wiadomo, że prace te nie dotrą do szerokiego kręgu uczonych pracujących

\footnotetext{
Międzynarodowy Instytut Biologii Molekularnej i Komórkowej w Warszawie oraz Fundacja na rzecz Nauki Polskiej

Prof. Maciej Żylicz jest kierownikiem Zakładu w Międzynarodowym Instytucie Biologii Molekularnej i Komórkowej, członkiem rzeczywistym Polskiej Akademii Nauk, prezesem Zarządu Fundacji na rzecz Nauki Polskiej, społecznym doradcą Prezydenta Rzeczypospolitej, doktorem honoris causa Uniwersytetu Wrocławskiego, Uniwersytetu Gdańskiego i Uniwersytetu Jagiellońskiego.
} 
w danej dziedzinie/dyscyplinie naukowej. Czy to jest promocja jakości nauki?

Osobnym zagadnieniem jest przeświadczenie, że za pomocą „impact factora” danego czasopisma można ocenić jakość opublikowanej tam przez habilitanta pracy. Nic bardziej mylnego! Jakość danej pracy można ocenić tylko stosując system oceny peer review, dokonany przez ekspertów w danej dziedzinie.

W 2014 r. FNP jako pierwsza instytucja w Polsce podpisała tak zwaną, Deklarację San Francisco”, w której zobowiązuje się między innymi do niestosowania parametrów oceniających czasopisma naukowe (takich jak np. impact factor) jako kryterium oceny naukowej jakości publikacji czy też oceny osiągnięć uczonych dokonywanej przy okazji awansów lub rozpatrywania ich wniosków o fundusze na badania naukowe. Fundacja, oceniając jakość badań naukowych, zawsze zwracała uwagę - także przed podpisaniem „Deklaracji San Francisco" - na oryginalność osiągnięć i ich wpływ na rozwój nauki i nie stosowała kryteriów właściwych do oceny czasopism, w których osiągnięcie to było publikowane. System oceny wniosków oparty na peer review, stosowany w FNP, jest przykładem pokazującym, że w Polsce, stosując takie procedury, można wyciągnąć bardzo dobre wnioski i ocenić oryginalność dotychczasowych osiągnięć naukowych indywidualnego naukowca.

W latach 2007-2015 FNP prowadziła dwa konkursy, TEAM i WELCOME, dla uczonych, którzy chcieli założyć swój pierwszy zespół badawczy lub rozbudować zespół już istniejący. Habilitacja nie była wymogiem formalnym w tym konkursie! W tabeli I przedstawiłem wstępną ocenę 84 zespołów, dokonaną przez Uniwersytet w Leiden. Wyniki te świadczą, że zastosowanie ostrych kryteriów oceny oryginalności badań naukowych w systemie peer review wystarczyło do stworzenia zespołów naukowych, które mają wyniki zdecydowanie lepsze od innych zespołów pracujących w Polsce.
Na podstawie tych danych stawiam hipotezę, że zniesienie habilitacji nie tylko nie załamie i tak już niskiego poziomu nauki uprawianej w Polsce, ale — przy zastosowaniu procedury peer review $w$ konkursach na zatrudnienie profesora nadzwyczajnego - może poprawić jakość badań naukowych prowadzonych w Polsce. Dla bardzo dobrych uczonych procedura habilitacyjna jest tylko przeszkodą w pracy naukowej. Natomiast słabi merytorycznie naukowcy zawsze znajdą Radę Wydziału, która oceni ich pozytywnie. Mogą teżzgodnie z nadal nieanulowanymi umowami rządowymi uzyskać habilitację w krajach postkomunistycznych.

Jeśli zależy nam na tym, aby mieć studentów zagranicznych, powinniśmy także zatrudniać w otwartych konkursach nauczycieli akademickich wykształconych za granicą. W każdym kraju istnieje inna procedura uzyskiwania samodzielności naukowej i możliwości promowania doktorów. Obecna procedura habilitacyjna w naszym kraju utrudnia zatrudnianie osób niepracujących w Polsce. Użyłem słowa „utrudnia”, a nie „uniemożliwia”. Oczywiście znam przepisy ustawy o stopniach i tytule naukowym, zgodnie z którymi Rada Wydziału/Instytutu, chcąc zatrudnić wybitnego uczonego z zagranicy, niemającego habilitacji, może uzyskać zgodę CK na wszczęcie postępowania o uzyskanie tytułu profesora. Problem jednak polega na tym, że dla wielu uczonych z zagranicy mających wybitny dorobek samo pytanie CK o taką zgodę jest żenujące! Recenzowałem kiedyś pracę habilitacyjną osoby z zagranicy, która była pierwszym autorem paru prac, za które jej szef dostał Nagrodę Nobla. Nie mogła zrozumieć, a tym bardziej jej szef, dlaczego musi przedstawić (w procentach) informacje, jaki był udział współautorów publikacji w stworzeniu tych dzieł!

Oczywiście zlikwidowanie habilitacji wymaga zgody całego środowiska naukowego, a przede wszystkim zmiany aktualnego systemu uprawiania i finansowania nauki w Polsce. Musi być to proces długotrwały, wymagający

Tabela I. Badania wykonane przez Centre for Science and Technology Studies, Leiden University, the Netherland

\begin{tabular}{lcc}
\hline Dane z lat 2002-2012 & $\begin{array}{c}\text { Udział w } \begin{array}{c}\text { 10\% najlepiej cytowanych prac } \\
\text { w dziedzinie }\end{array} \\
\text { TEAM (FNP) }\end{array} 11 \%$ & $\begin{array}{c}\text { Proporcja prac z udziałem międzynarodowej } \\
\text { współpracy }\end{array}$ \\
WELCOME (FNP) & $28 \%$ & $50 \%$ \\
UE28 & $11 \%$ & $62 \%$ \\
UK & $14 \%$ & $36 \%$ \\
Niemcy & $12 \%$ & $47 \%$ \\
Izrael & $12 \%$ & $46 \%$ \\
Francja & $11 \%$ & $42 \%$ \\
Włochy & $11 \%$ & $48 \%$ \\
Hiszpania & $10 \%$ & $41 \%$ \\
Węgry & $8 \%$ & $40 \%$ \\
Czechy & $7 \%$ & $53 \%$ \\
Polska & $5 \%$ & $47 \%$ \\
\hline
\end{tabular}


zmian w wielu ustawach i rozporządzeniach, co nie może nastąpić natychmiast.

Poniżej przedstawiam warunki, które - nawet w długiej perspektywie czasowej — powinny być wprowadzone, zanim zdecydujemy się na likwidację habilitacji.

1. Trzeba zmienić algorytm, zgodnie z którym finansowana jest dydaktyka. Algorytm ten nie powinien zależeć od liczby nowo zatrudnianych na uczelni profesorów nadzwyczajnych. Obecny algorytm zależy od liczby wypromowanych doktorów habilitowanych i profesorów, co prowadzi do częstych promocji miernych doktorów habilitowanych i profesorów tylko po to, aby uzyskać dodatkowe finansowanie.

2. Granty badawcze, uzyskiwane z zewnętrznych źródeł, powinny być powiększone o duże koszty pośrednie (minimum 50\%) lub dotacja statutowa powinna być proporcjonalna do środków uzyskanych z grantów badawczych. Zastępowałaby ona (w całości lub częściowo) obecną dotację na działalność statutową i byłaby powiększana o koszty utrzymania unikatowej aparatury badawczej (w tym dla humanistów o koszty utrzymania bibliotek). Wprowadzenie takiego sposobu naliczania działalności statutowej umożliwiłoby zlikwidowanie obecnej oceny parametrycznej oraz stworzenie systemu, w którym dziekanom i dyrektorom instytutu opłacałoby się zatrudniać najlepszych uczonych. Z kolei likwidacja oceny parametrycznej jednostek naukowych zapobiegałaby patologicznym zachowaniom środowiska naukowego przy ocenie indywidualnych osiągnięć naukowych (opisanych powyżej) oraz przerwałaby pogoń jednostek za promowaniem dużej liczby samodzielnych pracowników naukowych, niezbędnych do uzyskiwania uprawnień do nadawania stopni naukowych.

Niestety, obecny system uprawnień jednostek naukowych (bardzo szczodrze nagradzanych w systemie oceny parametrycznej) już się zdegenerował. Funkcjonujący w tym systemie podział na dziedziny i dyscypliny jest przestarzały i sztuczny. Na przykład Centralna Komisja ds. Stopni i Tytułów (CK) przyznaje uprawnienia, uwzględniając liczbę samodzielnych pracowników naukowych, posiadających stopień naukowy doktora habilitowanego i tytuł profesora w danej dziedzinie/dyscyplinie. Nie bierze jednak przy tym pod uwagę najważniejszego kryterium - czy są to czynni naukowcy i w jakich dziedzinach/dyscyplinach aktualnie publikują prace. Ponadto liczba samodzielnych pracowników naukowych w ostatnich 2-3 latach wzrosła znacząco, co nie zawsze jest zjawiskiem wyłącznie pozytywnym. Proponuję, aby to Polska Komisja Akredytacyjna, działając na nowych zasadach, przyznawała uprawnienia do prowadzenia danego kierunku studiów oraz uprawnień do nadawania stopnia doktora. Takie rozwiązanie doprowadziłoby do całkowitej likwidacji CK.
3. Należy wprowadzić możliwości bankructwa szkół publicznych. Jeżeli znajdą się Rady Wydziału, które będą nadal promowały awanse miernych naukowców, to powinien na to zareagować system finansowania dydaktyki i nauki. Promocja słabych badań, przeciętnych wyników i przeciętnych naukowców powinna skutkować stopniowym, ale bardzo zdecydowanym ograniczaniem dopływu środków budżetowych do takiej uczelni.W rezultacie ograniczonego finansowania takich jednostek system powinien doprowadzić je do bankructwa. Tylko wtedy doprowadzimy do promocji jakości uprawianej nauki w Polsce.

4. Proponuję także rezygnację z nadawania tytułu profesora przez Prezydenta RP. Przywilej zatrudniania na etatach profesora nadzwyczajnego (zatrudnienie na czas określony) oraz profesora zwyczajnego (zatrudnienie na czas nieokreślony) powinny mieć jedynie uczelnie spełniające odpowiednie warunki akredytacji. Likwidacja stopnia doktora habilitowanego mogłaby nastąpić pod warunkiem równoczesnego wprowadzenia systemu rzeczywistych, otwartych, międzynarodowych konkursów na stanowisko profesora nadzwyczajnego oraz zasady, że kandydat stający do konkursu — jeśli chce być zatrudniony na tej samej uczelni, na której uzyskał stopień doktora - musi odbyć przynajmniej dwuletni podoktorski staż naukowy poza macierzystą jednostką. Awans na samodzielne stanowisko (profesora nadzwyczajnego) powinien być rezultatem oceny peer review osiągnięć naukowych (rozumianych jako rzeczywisty wkład do nauki światowej). Awans powinien być rezultatem rozwoju naukowego, a nie jego celem.

O konieczności takich zmian w systemie uprawiania nauki w Polsce wskazuje ostatnio opublikowany artykuł prof. Marka Kwieka. 10\% polskiej kadry naukowej w Polsce tworzy 50\% całości, produkcji naukowej” (publikacji, monografii, patentów, wdrożeń) [1]. Pod tym względem nie odbiegamy od innych krajówUE. To potwierdza tezę, że dobra nauka jest tworzona przez elity. Pod względem umiędzynarodowienia nauki uprawianej przez polskie elity naukowe także nie różnimy się od swoich europejskich kolegów [1]. Ale — wg prof. Marka Kwieka z UAM — aż 43\% kadry naukowej w Polsce (biorąc pod uwagę okres analizowanych 3 lat) należy do grupy nieproduktywnej —osobyz tej grupy nie publikują, nie patentują nowych wynalazków, nie wdrażają swoich pomysłów do praktyki przemysłowej. Pod tym względem jest to najwyższy wskaźnik w Europie [1].

Chciałbym jednak uspokoić zwolenników utrzymania habilitacji — choć połączonego z podwyższaniem jej poziomu. Warunki niezbędne do tego, aby habilitację zlikwidować, pewnie jeszcze długo nie zostaną w Polsce zapewnione — niestety, moim zdaniem. Środowisko naukowe powinno jednak już o tym dyskutować — tak, aby w dającej się przewidzieć przyszłości udało się wprowadzić zmiany, które likwidację habilitacji uczynią możliwą i akceptowaną przez przeważającą większość naszego środowiska. 


\section{Prof. dr hab. Maciej Żylicz}

Międzynarodowy Instytut Biologii Molekularnej i Komórkowej w Warszawie

oraz Fundacja na rzecz Nauki Polskiej

e-mail: zylicz@fnp.org.pl

Otrzymano i przyjęto do druku: 24 kwietnia 2015 r.
Na podstawie wystąpienia podczas III Konferencji Naukowej czasopisma Nowotwory „Debaty onkologiczne" 10-11 kwietnia 2015 roku

\section{Literatura cytowana:}

1. Marek Kwiek.,Umiędzynarodowienie badań naukowych. Polska kadra akademicka z perspektywy europejskiej". (Tekst przyjęty do druku w: Nauka i Szkolnictwo Wyższe, Warszawa, 2015). 